\title{
Selection of the Korean Vowels on the E-Tran Board
}

\author{
Jeongeun Ko, Sangeun Shin \\ Department of Speech-Language Pathology, Chungnam National University, Daejeon, Korea
}

Correspondence: Sangeun Shin, PhD

Department of Speech-Language Pathology, Chungnam National University, 99 Daehak-ro,

Yuseong-gu, Daejeon, 34134, Korea

Tel: +82-42-821-6392

Fax: +82-42-823-3667

E-mail: sashin@cnu.ac.kr

Received: April 5, 2020

Revised: May 13, 2020

Accepted: May 13, 2020

This paper was extracted from the Master's thesis of the first author (2020).

\begin{abstract}
Objectives: An E-Tran board, a non-electronic communication aid, is widely used for individuals with complex communication needs in English-speaking countries. In particular, those who have very limited physical movement but functional literacy skills can benefit from this low-tech system, which uses only their eye movement for alphabet selection. Despite the strengths of the E-Tran board, lack of effort was made in Korea, which hinders Korean AAC users from having the chance to communicate effectively with others. Considering the fact that the Korean language has complex vowel systems, such as diphthongs, the present study aims to investigate the effects of vowel selection in the E-Tran board and the vowel type of the target non-words in terms of accuracy and response time. Methods: Thirty normal adults participated in this study (mean age $=24.6$ years, $\mathrm{SD}=1.8$ ). They performed a non-word generation task using two types of boards (single selection of diphthongs vs. double selection of monophthongs). Results: Results showed that the single selection of diphthongs showed more accuracy scores and faster response time. Notably, when generating the target words with diphthongs, participants performed better in the E-Tran condition of single selection. Conclusion: The E-Tran board is expected to help Korean AAC users to communicate more efficiently through the single selection of monophthongs and diphthongs. Further research is needed to identify the effect of the single vowel selection across a wide range of language units composing of meaningful words.
\end{abstract}

Keywords: Augmentative and alternative communication, E-Tran, Vowel selection, Literacy skills, Adults
문해력이 보존된 보완대체의사소통(augmentative and alternative communication, AAC) 사용자들은 비전자적 방식인 로우테 크(low-tech)부터 정교한 전자적 방식인 하이테크(high-tech)까지 다양한 글자기반의 $\mathrm{AAC}$ 접근방법을 사용하여 의사소통 할 수 있 다(ASHA, 2004; Beukelman \& Mirenda, 2013). 가령 로우테크 방 식의 일환으로 종이에 직접 원하는 바를 글로 쓰거나 의사소통판 에서 한글 자소를 조합하여 대화 상대방이 이를 시각적으로 읽고 이해하도록 할 수 있으며, TTS (text-to-speech) 기능을 탑재한 하이 테크 $\mathrm{AAC}$ 도구를 사용하여 텍스트를 생성한 후 음성으로 산출하 여 상대방과 소통할 수도 있다.

이들 $\mathrm{AAC}$ 접근방법은 개인의 운동능력을 고려한 적합한 선택 방법(method of selection)을 통해서 이루어질 수 있는데(Goossens' \& Crain, 1987), 손, 머리, 눈, 또는 발과 같은 신체부위의 움직임이 기능적인 사용자들은 직접 자신이 원하는 글자나 단어를 인쇄된
의사소통판이나 하이테크 AAC 기기나 애플리케이션을 통해 가리 킬 수도 있겠고, 필요 시 컴퓨터 보조접근장치를 통해 이러한 직접 선택(direct selection)을 도모할 수 있을 것이다. 또는 조금이나마 움직일 수 있는 신체부위를 찾아 내어, 간접선택(indirect selection) 을 활용할 수도 있다(Cook \& Hussey, 2002). 예를 들어 대화 상대 자의 도움에 의존한 시청각적 스캐닝(partner-assisted auditory/visual scanning) 방법을 이용하는 로우테크 방식이나 컴퓨터 보조접 근장치를 이용한 스캐닝 방법의 하이테크 방식이 그 예이다.

$\mathrm{AAC}$ 사용자의 입장에서는 의사소통의 정확성과 속도, 편의성 면에서 스캐닝 기반으로 이루어지는 간접선택보다는 직접선택을 통해 자신이 산출하고자 하는 메세지를 생성하는 것이 효율적이다 (Beukelman \& Mirenda, 2013; Kim, Park, Han, \& Ku, 2016). 그러 나 뇌성마비, 근위축성측색경화증(amyotrophic lateral sclerosis, $\mathrm{ALS}$ ), 잠금증후군(locked-in syndrome)과 같이 선천적 또는 후천 
적 장애로 인해 신체 움직임이 크게 제한된 경우에는 직접선택을 위해 고가의 보조접근장치를 구비해야 하는 사용자 측 부담이 발 생하며, 장비의 유지 및 수리비용과 수리기간 동안의 의사소통 단 절 상황 또한 고려를 해야 한다. 현재 국내에는 정부 및 각 지자체가 정보통신보조기기 사업과 보조기기센터를 통해 의사소통보조기 기와 컴퓨터보조접근장치의 사용을 지원하고 있으나, 다양한 장비 를 수요에 맞춰 보유하고 있지는 않기 때문에 언제라도 간편하게 사용할 수 있으면서 비용부담이 크지 않은 개인맞춤의 글자기반 로 우테크 도구의 개발에도 관심을 기울일 필요가 있겠다. 로우테크 활용의 효과성은 Harris와 Goren (2009)의 연구를 통해서 알 수 있 는데, 영어권에서 사용하는 하이테크 도구인 ERICA와 로우테크 인 알파벳 보드를 ALS 환자에게 적용한 결과, 글자판으로 의사소 통 하는 속도가 더 빠른 것으로 나타났다. 이는 컴퓨터 사용에 익숙 하지 않은 사용자들의 피곤(fatigue)도가 수행에 영향을 주었기 때 문으로 확인되었다. Harris와 Goren (2009)의 연구결과를 모든 장 애인에게 일반화할 수는 없겠으나 운동능력의 결함이 두드러지는 장애인의 경우 로우테크가 효과적으로 사용될 수 있다는 가능성 을 보여준다 하겠다.

특히 로우테크 도구 중 하나인 눈 응시를 통한 E-Tran 보드의 사 용은 문해력이 보존된 중증의 신체 장애인들에게 적용할 수 있는 효과적인 AAC 접근법 중의 하나로(Eichler, 1973; Vandertheiden, 1980) 하이테크를 대체할 수 있는 좋은 대안이 될 수 있다. E-Tran 이란 대상자들의 독립적인 안구 응시를 통해 음소를 직접 선택할 수 있는 의사소통 도구로, 대개 직사각형 모양의 보드에 중앙이 딿 려 있는 투명한 플렉시(plexiglass)로 제작된다. E-Tran 보드에 배치 할 수 있는 자소는 최대 64개까지(Goossens' \& Crain, 1987)로, 가 독성을 높이고 수행의 정확성을 높이기 위해 영어권에서는 36 개 내외(Swift, 2012)의 자소, 숫자, 또는 단어가 놓일 수 있는 공간배치 가 선택되는 편이다. 가령 알파벳의 경우, E-Tran 보드의 네 모서리 와 위 아래의 가운데 부분에 총 6 개의 그룹형태로 배치되며, 하나 의 그룹에는 6 개의 자소가 포함되는데, 이 자소의 색상은 E-Tran 보드의 그룹 별 위치 색상과 의도적으로 동일하게 지정된다. 색상 을 동일하게 지정하는 이유는 보드의 제한된 물리적 공간에 배치 된 자소를 사용자가 선택할 때마다 대화 상대방이 이를 손쉽게 확 인할 수 있도록 하기 위함이다. 좀 더 자세히 설명하자면, 사용자는 자신이 원하는 자소가 위치한 그룹을 E-Tran 보드의 6개 위치 중 에서 눈 응시를 통해 선택하게 되며, 이후 해당 음소의 색상을 ETran 보드의 6개의 위치에 지정된 색상 중에 선택하게 된다. 따라 서 사용자는 최소 두 번의 눈 응시가 요구되는데, 한번은 자소가 속 한 그룹을 다른 그룹들과 구분하여 선택하기 위한 것이며, 또 하나
는 그 그룹 내에서 목표 자소를 비목표 자소들과 구분하여 선택하 기 위해 보드 위에 부착된 색상을 찾아 눈으로 가리키게 되는 것이 다. 대상자가 두 번의 눈 응시를 마치면, 의사소통 촉진자(facilitator)는 이를 확인하고 다음에 선택되는 음소들과 결합하여 말로 산 출해주는 역할을 하게 된다(Goossens' \& Crain, 1987; Kate \& Hepp, 1989; Sigafoos \& Couzens, 1995). 따라서 E-Tran은 사용자가 원하 는 자소를 직접 응시하여 선택할 수 있다는 점에서 보면 직접선택 의 특성을 갖고 있으나, 한 번의 선택이 아닌 두 번의 선택 절차가 요 구된다. 또한 최종적으로 자소를 선택하는 시점에서 대화 상대방 의 확인이 필요한 직접선택 방식과 다르게, 두 번의 선택과정 모두 에서 대화 상대방의 피드백이 중요하게 작용하기 때문에 상대방이 두 과정 중 하나라도 잘못 확인할 경우 원하지 않는 자소가 선택되 어질 수 있다.

E-Tran은 신체적 움직임이 많이 제한된 사용자라 하더라도 안구 움직임은 대체로 보존된 경우가 많기 때문에(Mitsumoto, 2009) 하 이테크 도구의 도움 없이도 의사소통을 가능하게 한다는 장점이 있다. 또한, 휴대가 간편하고 고장의 위험이 없으며, 중환자실이나 병동과 같이 환자 주변에 의료장비가 작동되는 환경에서도 안전하 게 의사소통 할 수 있다. 이러한 장점 때문에 영어권 국가에서는 일 찍이 의료기관이나 교육현장에서 E-Tran을 활발히 사용해 왔고, 체계적인 알파벳 음소배열 방식이 확립되어 있다(Kate \& Hepp, 1989; Sigafoos \& Couzens, 1995). 실제 E-Tran 보드를 뇌성마비와 지적장애를 동시에 보이는 아동에게 적용하여, 기능적 의사소통 기술을 교수한 선행 연구(Sigafoos \& Couzens, 1995)를 살펴보면, 물건 요구하기의 의사소통 기술을 빠르게 습득하는 것으로 나타 났다. 이러한 결과는 성인 뿐만 아니라 아동에게도 E-Tran이 효과 적인 중재가 될 수 있다는 것을 보여준다(Sigafoos \& Couzens, 1995).

E-Tran이 갖고 있는 장점을 국내 AAC 사용자들에게도 적용하 기 위해서는 한글 자소를 기반으로 한 도구 개발이 필요하며 영어 와는 다른 음운체계를 이해하는 것이 선행되어야 할 것이다. 한국 어 음소는 자음 19 개, 단모음 10 개( I, 게, ㅐ, 기, 기, T, ㄴ, _, ㄱ,

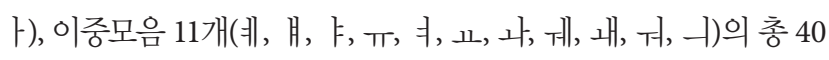
개 음소로 구성되어 있으며 특히 이중모임 체계가 발달되어 있다 (Park, 2017). 이는 영어권에서 E-Tran의 36개의 공간에 26개의 알 파벳과 10 개의 고빈도 단어나 숫자 등을 포함하여 배치할 수 있는 것과는 다르게 한국어 사용자를 위해서는 별도의 공간배치와 접근 방식이 필요하다는 것을 말해준다. 따라서 한국어 기반의 E-Tran 보드는 한글 자소를 위한 공간 42 개 외에 단어 배치를 위한 추가 공 간이 필요할 수 있으며, 이를 위해 플랙시 판의 가운데 뚫린 부위 양 옆으로 공간을 사용하는 방법이 제안될 수 있겠다. 그렇게 되면 
36 개에서 12 개의 공간이 늘어난 48 개의 공간활용이 가능해진다. 그러나 확장된 공간에서 자소와 의미단어의 배치 비율을 적절히 배분하는 것은 또 다른 주요한 고려 사항이 된다. 가령 '예', '아니 오', '모르겠어요, ‘그만 할래요' 등 대화 시 자주 사용하고 빠르게 산출될 필요가 있는 단어에 대해서는 반응시간이 오래 걸리는 자 소 결합의 방식보다는 직접 단어를 E-Tran 판에서 선택하도록 하 는 것이 효율적일 것이다. 만약 이중모음을 그대로 E-Tran 보드의 공간에 배치하지 않고, 단모음의 결합을 통해서 일부라도 산출하 도록 한다면 그만큼 공간이 절약되어 단어 배치에 활용할 수 있을 것이다. 그러나 만일 이러한 단모음 결합 방식이 의사소통 속도를 저해할 경우에는 단어를 위한 공간활용도를 상대적으로 낮춘다 하 더라도 모든 모음체계를 그대로 제시하여 사용자가 동일한 조건에 서 선택할 수 있도록 하는 방법이 필요할 것이다.

국내에는 아직까지 글자기반의 E-Tran이 개발되어 활용되고 있 지 않은 바, 본 연구에서는 한국어 기반의 E-Tran 보드 개발을 위한 기초연구로써 문해력을 갖춘 정상 성인을 대상으로 모음 선택 방식 과 목표 자극어의 모음유형에 따라 E-Tran의 수행 정확도와 반응 시간에 차이가 나타나는지를 살펴보고자 하였다. 목표 자극어의 모음유형을 독립변수로 추가한 이유는 두 개의 조건으로 제작된 E$\operatorname{Tran}$ 보드가 자음+이중모음으로 구성된 목표 자극어뿐만 아니라 자음+단모음으로 구성된 목표 자극어에 대해서도 영향을 주는지 를 살펴보고 연구결과를 중재에 활용하기 위해서이다. 연구질문은 다음과 같다.

첫째, 단모음과 이중모음으로 구성된 1 음절의 비단어 생성과제 에서 E-Tran 보드를 두 가지 모음선택 조건(이중모음 단독선택 조 건 vs. 단모음 복수선택 조건)에서 적용하였을 때 정반응 수에 있어 서 유의한차이가 있는가?

둘째, 단모음과 이중모음으로 구성된 1 음절의 비단어 생성과제 에서 E-Tran 보드를 두 가지 모음선택 조건에서 적용하였을 때 반 응시간에 있어서 유의한 차이가 있는가?

\section{연구방법}

\section{연구대상}

본 연구는 대전 지역에 거주하는 20 대 성인 30 명을 대상으로 하 였다. 모두 한국어를 모국어로 사용하는 자로, 최종학력은 고등학 교 졸업 이상으로 하였다. 정신 - 신경학적 병력과 심각한 시각 및 청 력의 문제 등이 인터뷰 과정에서 확인된 경우는 배제하였다. 실험 과제의 수행에 필요한 기본적인 문해력을 선별하기 위해 실어증-신 경언어장애선별검사(STAND; Kim, Heo, Kim, \& Kim, 2009)의 하
위검사인 읽기 검사에서 정반응을 보인 경우만 본 실험에 참여하 였다. 읽기 항목은 검사지침에 따라 실시하되, 제시되는 글자의 크 기는 본 실험에서 모니터를 통해 제시되는 자극물의 글자 크기와 동일하도록 하였다.

선별검사를 통과하고 본 실험에 참여한 연구 참여자는 남자 15 명, 여자 15명으로 평균 연령은 24.6세( $\mathrm{SD}=24.6, \mathrm{Max}=28, \mathrm{Min}=22)$ 였고, 평균 교육년수는 16.1 년(SD=1.16, $\mathrm{Max}=19, \mathrm{Min}=13)$ 이었다.

\section{연구도구}

\section{$\mathrm{E}-$ Tran 보드의 개발}

본 연구에서 사용된 E-Tran은 가로 $43.2 \mathrm{~cm} \times$ 세로 $29.2 \mathrm{~cm}$ 의 투 명 아크릴판에 가운데가 뚫려 있는 형태로 제작하였다. E-Tran에 자소를 배치할 때에는 전체 직사각형의 영역을 6 등분으로 구분하 여 빨간색, 파란색, 회색, 초록색, 검은색, 주황색으로 위치를 지정 한 후, 영역 별로 6 개의 자소 묶음을 배치하고, 전체의 영역에 대응 되는 색깔 코딩을 각각의 자소에 적용하였다. 한국어의 자소가 많 은 점을 고려하여 가운데 열에 두 영역을 추가하였으며 자소의 색 깔 코딩작업은 6 개의 색 범위 내에서 동일하게 이루어지도록 하였 다. 자소는 microsoft office의 Powerpoint 2016 프로그램을 이용하 여 글자크기 72 포인트의 바탕체로 제작하였다. 제작된 자소 영역 은 출력 후 두 개의 E-Tran에 각각 부착하였다.

모음 선택 방식은 Figure 1에 제시된 바와 같이, 단모음의 조합을 통해서 이중모음을 생성할 수 있는 단모음 복수 선택 조건의 보드 와 개별적으로 이중모음을 선택할 수 있는 이중모음 단독 선택 조 건의 보드로 구분하여 제작하였다. 단, 단모음 복수 선택 조건에서

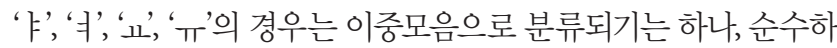
게 한글 모음체계에 있는 단모음의 조합만으로 생성이 불가하므로 그대로 보드에 제시되도록 하였다. 자음은 자연스러운 구어 상황 에서 음소 별 사용빈도의 차이가 있기는 하나 다양한 자음이 사용 되는 만큼(Shin, 2008), 두 조건 동일하게 모든 자음이 단독 선택될 수 있도록 가나다순으로 배치하였다.

모음은 '아야어여오요우유'의 순으로 배열하되, 모음의 수가 조 건에 따라 달라짐에 따라 임상에서의 활용성을 고려하여 그 위치 를 조정하였다. 가령 이중모음 단독 선택 조건에서(Figure 1A)는 늘 어난 이중모음의 공간배분을 고려하여 '',' 'k', '',' 'A'에 해당하는 모음을 가운데 층위로 이동하되, 가장 왼쪽 공간은 의사소통 촉진 자가 E-Tran을 손으로 잡아야 하므로 배제하였다. 단모음 복수 선 택 조건(Figure 1B)에서는 모음의 숫자가 줄어든 만큼 모음은 모두 E-Tran의 하단 층위에 오른쪽부터 체계적으로 배치하였다. 자소 가 배치되지 않은 공간은 빈 네모 칸 처리를 하여 추후 임상단계의 


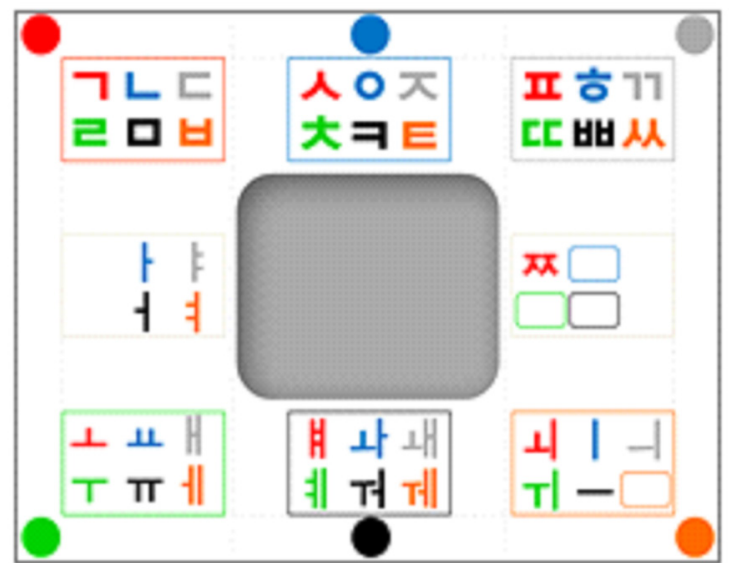

(A)

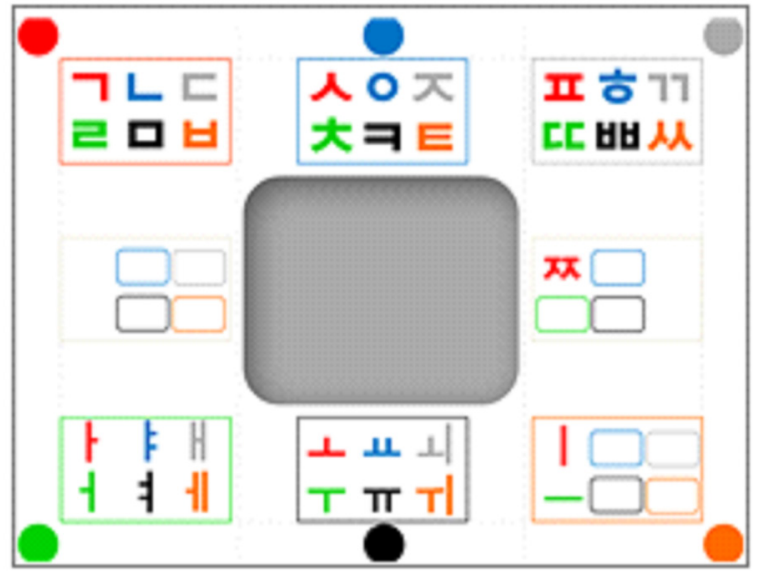

(B)

Figure 1. $E$-Tran board $(A=$ single selection of diphthongs, $B=$ double selection of monophthongs $)$.

연구에서 의미단어가 들어갈 수 있도록 확보해 두었다.

\section{실험 자극어}

본 연구는 모음 선택 방식에 따른 E-Tran 보드에서의 수행차이 를 살펴보는데 초점을 두었기 때문에 의미단어가 피험자에게 미치 는 친숙성의 영향을 배제하고자 1 음절의 비단어로 구성된 실험 자 극어를 개발하였다. 자극어는 단모음 유형 10 개와 이중모음 유형 10 개, 총 20 개를 제작하였으며 무작위순으로 컴퓨터 모니터를 통 해 제시되도록 하였다. 단모음 유형은 E-Tran의 모음 선택 방식과 상관없이 한 번의 모음 선택만으로 목표 자극어를 산출할 수 있는 자음+단모음의 CV형태(예: 로, 주)를 말하며 이중모음 유형은 E$\operatorname{Tran}$ 의 모음 선택 방식에 영향을 받을 수 있는 자음+이중모음의 $\mathrm{CV}$ 형태(예: 롸, 줴)를 말한다.

이중모음으로 구성된 비단어를 개발할 때에는 자음의 유형과 배 치된 공간위치가 수행에 미치는 영향을 최소화 하기 위하여 단모 음 항목으로 개발된 자극어에서 모음을 하나 더 추가한 형태로 제 작하였다(예: 단모음이 사용된 '로'에 대해서 모음 ''가 추가된 이 중모음 형태의 '롸' 개발).

자극어는 E-Tran에 배치된 다양한 위치의 자소가 실험에 포함되 도록 함으로써 자소의 위치가 수행에 미치는 영향을 통제하였다. 또한 동일한 실험 자극어 20개에 대하여 E-Tran 보드의 조건(이중 모음 단독 선택 vs. 단모음 복수 선택)별로 실시하되 조건 간의 순서 효과를 차단하기 위하여 균형배정(counter balance)하였다.

\section{연구절차}

본 연구는 독립된 조용한 실험실에서 실시되었으며, 모든 피험자 는 1 회 방문하여 실험을 마치도록 하였다. 실험 시작 전에 피험자에

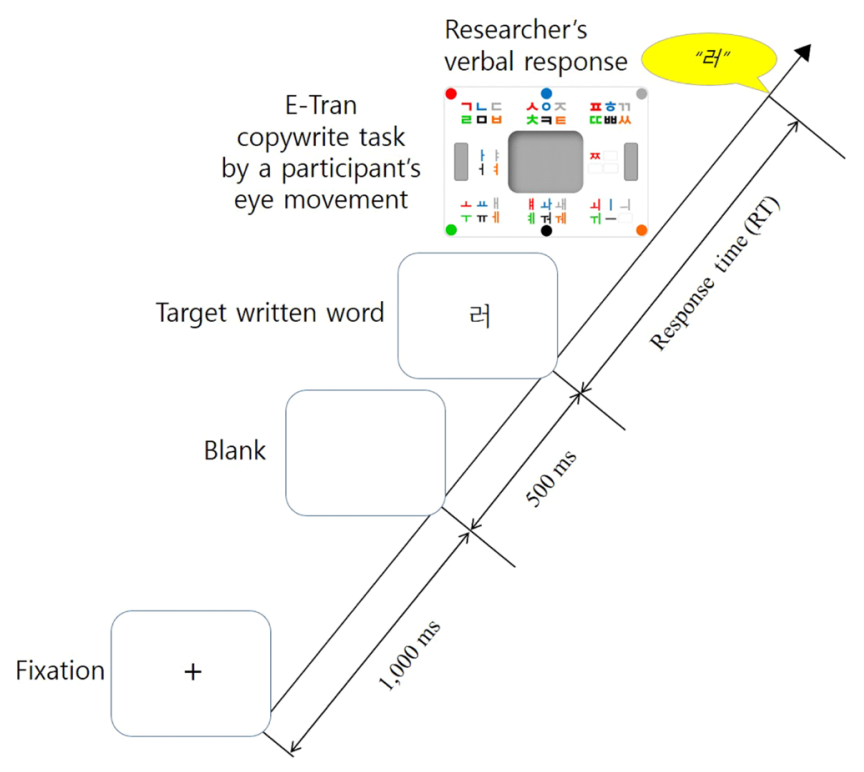

Figure 2. Task procedures of non-word generation task using E-Tran boards.

게 서면으로 작성된 연구 설명서를 구두로 전달하고, 연구 참여에 대한 동의서에 서명을 받은 후 선별검사를 실시하였다.

비단어 생성과제에서는 연습문항 3 개를 미리 실시하여 피험자 가 과제를 정확하게 이해하였다는 것을 확인한 후, 본 실험을 실시 하였다. 과제지침은 컴퓨터 모니터를 통해 시각적으로 제시하였고 동시에 검사자가 이를 구두로도 전달하도록 하였다. 비단어생성과 제의 세부 연구절차는 Figure 2에 제시된 바와 같다. 우선 피험자가 화면의 십자표시 ‘+'를 $1,000 \mathrm{~ms}$ 동안 응시하고 자동으로 빈(blank) 화면이 $500 \mathrm{~ms}$ 동안 제시되고 나면, 단모음과 이중모음 조건의 실 험자극어가 무작위로 화면에 $10,000 \mathrm{~ms}$ 동안 제시되도록 실험절차 와자극의 노출시간은 통제하였다. 피험자의 반응시간은 목표 비단 
어가 제시되는 순간(onset time of written words' presentation)부 터 눈응시를 통한 E-Tran 수행을 마치고 검사자가 응시한 자음과 모음을 결합하여 구두로 산출하기 시작한 시점(onset time of a researcher's verbal response)까지로 하였으며 정확한 onset time의 측정을 위해 비단어가 화면에 제시되는 순간에 beep sound가 산출 되도록 하였고, 모든 반응시간은 과제수행을 녹음한 후 PRAAT (Boersma \& Weenink, 2019)으로 반응시간을 측정하였다. 이때 말 소리 파형에서 검사자의 구두산출 시점을 측정하는 기준은 한국 어의 초성 자음의 말소리 특성(Shin, 2011)에 준하였다. 정확한 음 성 녹음을 위해 녹음기(Olympus VN-702PC/VN-701PC)를 사용 하였다.

\section{자료분석 및 통계처리}

E-Tran 과제에서의 정반응 수는 목표 자극어의 자음과 모음 산 출이 모두 맞으면 1점, 둘 중 하나라도 틀리면 0점으로 채점하여 피 험자 별 총점을 산출하였다. 반응시간은 정확하게 수행한 항목에 대해서만 분석하였다. 목표 자극어의 모음유형(단모음 vs. 이중모 음)에 따라 모음 선택 방식(이중모음 단독 선택 조건 vs. 단모음 복 수 선택 조건) 간에 정반응 수와 반응시간의 차이가 있는지를 살펴 보고, 각각의 모음 선택 방식 별로 과제 전반부와 후반부 간의 목표 자극어의 모음유형에 따른 차이가 있는지를 살펴보기 위하여 $2 \times$ 2 반복측정 이원분산분석(repeated measures two-way ANOVA) 을 실시하였다. 통계분석은 IBM SPSS version 24 를 이용하였다.

분석한 정반응 수와 반응시간에 대한 신뢰도를 검증하기 위하 여 전체 자료의 $10 \%$ 에 해당하는 자료를 무작위로 추출하여 평가 자 간 신뢰도(inter-rater reliability)를 산출하였다. 신뢰도 검사에 참여한 평가자는 연구자(제 1 평가자)와 언어병리학 석사과정을 수 료한 학생(제 2 평가자)이다. 신뢰도 검사를 실시하기에 앞서 제 1 평가 자는 제 2 평가자에게 채점기준과 Praat을 이용한 반응시간 분석방 법을 숙지하도록 오리엔테이션 과정을 거쳤고, 두 평가자는 독립적 으로 분석을 하였다. E-Tran 과제의 총점에 대한 신뢰도는 카파계

Table 1. Mean and standard deviation of accuracy scores in the non-word generation task

\begin{tabular}{lcccc}
\hline Vowel type of target items & $\begin{array}{c}\text { Vowel selection type } \\
\text { in the E-Tran }\end{array}$ & Mean & SD & N \\
\hline Monophthongs & Single selection & 9.70 & .47 & 30 \\
& Double selection & 9.40 & .72 & 30 \\
Diphthongs & Single selection & 9.53 & .82 & 30 \\
& Double selection & 9.13 & .97 & 30 \\
\hline
\end{tabular}

$\mathrm{SD}=$ standard deviation; $\mathrm{N}=$ number of subjects 수(coefficient of kappa)로 분석하였으며, 과제 총점의 신뢰도는 0.94 , 반응시간의 신뢰도는 0.8 로, 평가자 간 높은 일치도를 보였다.

\section{연구결과}

\section{E-Tran 보드의 모음 선택 방식과 목표 자극어의 모음유형에 따른 정반응 수 차이}

1 음절 비단어 생성과제에서 모음 선택 방식에 따른 평균 정반응 점수를 포함한 기술통계 결과는 Table 1과 Figure 3 에 제시된 바와 같다. 목표 자극어가 자음+단모음의 CV형태인 경우가 자음+이중 모음인 경우보다 전반적으로 평균 정반응 수가 높았으며, 각각의 목표 자극어 형태 별로 살펴보면, 이중모음을 단독으로 선택하는 E-Tran 보드에서의 평균정확도가 단모음을 복수 선택해야 하는 조 건에서보다 평균 정반응 수가 더 높은 것으로 나타났다.

모음 선택 방식과 목표 자극어의 모음유형에 따라 정반응 수에 서 유의한 차이가 있는지를 살펴보기 위해 반복측정 이원분산분 석을 실시한 결과 모음유형 $\left(F_{(1,29)}=2.951, p=.097\right)$ 에 대해서는 주 효과가 나타나지 않았으나 모음 선택 방식 $\left(F_{(1,29)}=4.721, p=.038\right)$ 에 대해서는 유의한 차이가 나타났다. 이중모음 단독 선택 조건으 로 제작된 E-Tran을 사용하였을 때가 단모음 복수 선택 조건으로 제작된 E-Tran을 사용했을 때보다 정반응수가 유의하게 더 많은 것으로 나타났다. 모음유형과 모음 선택 방식 간의 상호작용효과 는 유의하지 않았다 $\left(F_{(1,29)}=0.143, p=.708\right)$.

모음 선택 방식에 대한 주효과가 어느 목표 자극어의 모음유형 조건에서 나타나는지를 살펴보기 위해 본페로니 교정(Bonferroni correction)을 적용한 유의수준 .025 (.05/2)에서 대응표본 $t$ 검정 (paired $t$-test)을 실시하였다. 그 결과 유의한 차이를 보이는 모음유 형은 없는 것으로 나타났다(단모음 $t_{(29)}=1.964, p=.059$; 이중모음 $\left.t_{(29)}=1.588, p=.123\right)$.

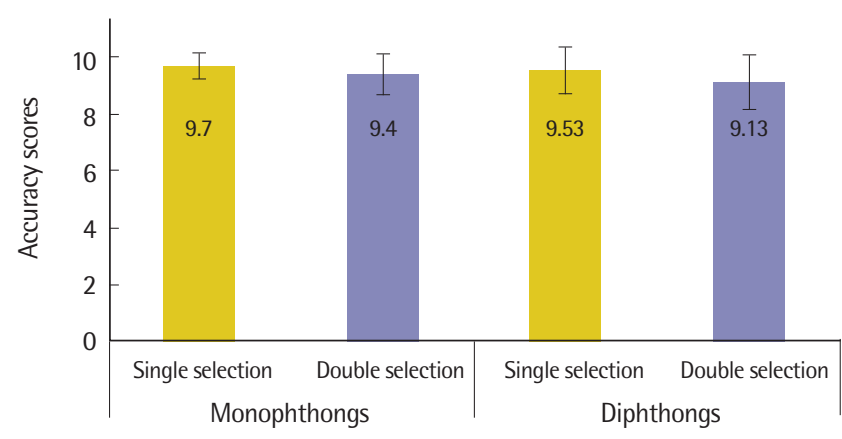

Figure 3. Accuracy scores in the non-word generation task using E-Tran boards. 
Table 2. Mean and standard deviation of response time(s) in the non-word generation task

\begin{tabular}{lcccc}
\hline Vowel type of target items & $\begin{array}{c}\text { Vowel selection type } \\
\text { in the E-Tran }\end{array}$ & Mean & SD & N \\
\hline Monophthongs & Single selection & 19.73 & 2.33 & 241 \\
& Double selection & 19.72 & 2.43 & 241 \\
Diphthongs & Single selection & 20.19 & 2.65 & 241 \\
& Double selection & 23.24 & 3.05 & 241 \\
\hline
\end{tabular}

$\mathrm{SD}=$ standard deviation; $\mathrm{N}=$ number of subjects.

\section{E-Tran 보드의 모음 선택 방식과 목표 자극어의 모음유형에 따른 반응시간 차이}

1음절 비단어 생성과제에서 E-Tran의 모음 선택 방식에 따른 평 균 반응시간을 포함한 기술통계 결과는 Table 2와 Figure 4에 제시 된 바와 같다. 목표 자극어의 형태가 자음+단모음인 경우가 자음+ 이중모음인 경우보다 전반적으로 평균 반응시간이 짧았으며, 각각 의 목표 자극어 형태별로 살펴보면, 이중모음을 단독으로 선택하 는 E-Tran 보드에서의 평균 반응시간이 단모음을 복수 선택해야 하는 조건에서보다 더 짧은 것으로 나타났다.

모음 선택 방식과 목표 자극어의 모음유형에 따라 반응시간에 유의한 차이가 있는지를 살펴보기 위해 반복측정 이원분산분석을 실시한 결과, 모음유형 $\left(F_{(1,240)}=298.296, p<.001\right)$ 과 모음 선택 방식 $\left(F_{(1,240)}=120.723, p<.001\right)$ 모두에서 유의한 주효과가 나타났으며 모음유형과 모음 선택 방식 간의 상호작용효과도 유의한 것으로 나 타났다 $\left(F_{(1,240)}=212.949, p<.001\right)$.

목표 자극어의 모음유형별로 어떠한 E-Tran 선택조건에서 유의 한 차이를 보이는지를 살펴보기 위하여 교정된 유의수준(.05/2 $=.025)$ 에서 대응표본 $t$ 검정(paired $t$-test)을 실시한 결과 자음+단모음 $\left(t_{(274)}=-.723, p=.470\right)$ 에서는 유의한 차이가 없었으나, 자음 + 이중모 음의 1음절 목표 자극어를 산출하는 항목에 대해서는 이중모음을 단독 선택하는 E-Tran 보드 환경이 단모음을 복수 선택해야 하는 환경보다 반응시간이 유의하게 더 짧은 것으로 나타났다 $\left(t_{(260)}=\right.$ $-16.421, p<.001)$.

마찬가지 방식으로 E-Tran의 모음 선택조건별로 어떠한 목표 자 극어의 모음유형에서 유의한 차이를 보이는지를 살펴보기 위하여 교정된 유의수준 .025 에서 대응표본 $t$ 검정을 실시한 결과 이중모 음 단독 선택 조건의 E-Tran에서 자음+단모음의 목표 자극어를 산 출할 때가 자음+이중모음을 산출 할 때보다 반응시간이 짧았으며 $\left(t_{276)}=-3.515, p<.01\right)$, 단모음 복수선택 조건의 E-Tran 보드에서도 두 모음유형 간의 차이가 유의하였다 $\left(t_{(259)}=-23.703, p<.001\right)$.

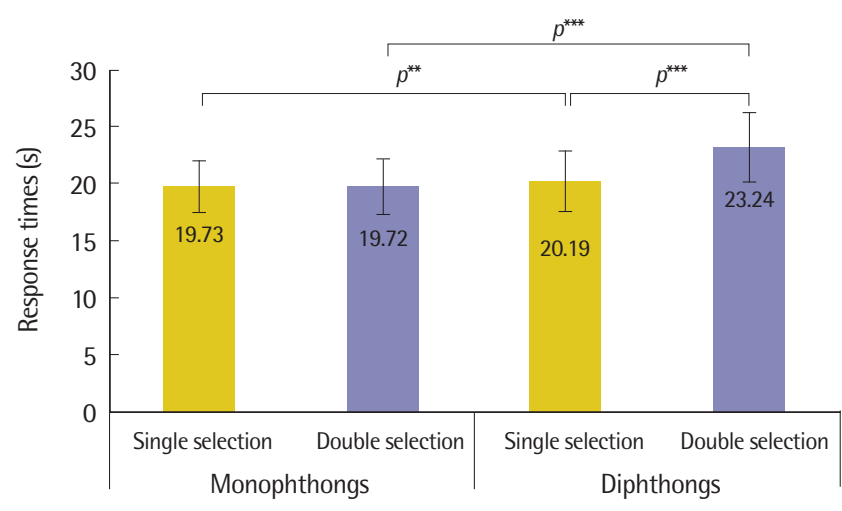

Figure 4. Response times in the non-word generation task using E-Tran boards.

${ }^{* *} p<.01,{ }^{* * *} p<.001$.

\section{논의 및 결론}

본 연구는 정상 성인을 대상으로 모음 선택 방식과 목표 자극어 의 모음유형에 따라 E-Tran의 수행 정확도와 반응시간에 차이가 나타나는지를 살펴본 연구로, 결과를 요약하면 다음과 같다. 모음 선택 방식과 목표 자극어의 모음유형에 따라 정반응 수의 유의한 차이가 있는지를 살펴본 결과, 이중모음 단독 선택 조건으로 제작 된 E-Tran을 사용하였을 때가 단모음 복수 선택 조건으로 제작된 E-Tran을 사용했을 때보다 더 정확하게 단모음 또는 이중모음으로 구성된 목표 자극어를 산출할 수 있는 것으로 나타났다. 이러한 결 과는 연구에 참여한 피험자 모두 문해력에 문제가 없는 성인이라 하더라도 자연스럽지 않은 로우테크 AAC 도구를 활용한 글자 전 달 상황에서는 E-Tran의 모음배열의 특성이 피험자의 눈 응시를 통한 선택 횟수에 영향을 주고, 그로 인해 정확도 측면에서도 더 많 은 눈 응시와 검사자의 구두 확인 과정을 필요로 한 단모음 복수 선 택 조건의 E-Tran 보드에서 정확도가 더 낮아지는 결과를 초래한 것으로 보인다. 그러나 이러한 정확도의 차이는 목표 자극어가 자 음+단모음이든 자음+이중모음이든 크게 영향을 받지는 않는 것으 로 보여 측정치인 정확도가 목표 자극어의 모음 특성을 민감하게 반영하지는 않는 것으로 보인다.

추후 문해력이 있는 사용자가 메시지 내용 전달의 정확도만을 고려하여 E-Tran을 사용하고자 할 경우에는 그 메시지가 다양한 모음유형을 포함한다 하더라도 수행에는 큰 영향을 미치지 않을 것으로 보이나, 이중모음을 단독으로 선택할 수 있도록 제작된 E$\operatorname{Tran}$ 이 정확도 측면에서는 보다 더 의사소통능력을 도모하는 데 쓰여질 수 있을 것이기 때문에 이 조건의 E-Tran 사용을 권장할 수 있겠다. 
또한 사용자 중에는 선천적 또는 후천적인 장애로 인해 기능적 인 문해력은 보이나 정상 성인의 수준만큼은 아닌 경우도 있을 수 있다. 만약 장애로 인해 일부라도 음운인식(phonological awareness)의 손상을 동반한 경우, 말소리를 분절(segments)하고 추상화 하는 능력에 영향을 받아(Morais, Alegría, \& Content, 1987; Wagner \& Torgesen, 1987), 단어의 철자 표현에 어려움이 초래될 수 있 다(Brady \& Shankweiler, 1991). 따라서 음운인식능력이 다소 낮은 이들에게는 단모음을 결합하여 이중모음을 생성해내야 하는 단모 음 복수 선택 조건의 E-Tran 보드를 사용하는 것보다는 이중모음 이 보드 위에 그대로 제시되어 선택될 수 있도록 하는 게 보다 정확 성을 높일 수 있을 것으로 보인다. 구어를 사용할 수 없는 사람은 쓰 기에서 음운지식을 성공적으로 사용하는데 어려움을 겪는다는 연 구들이 많이 보고되고 있다(Berninger \& Gans, 1986; Hart, Scherz, Kenn, \& Hodson, 2007; Sandberg \& Hjelmquist, 1996). 본 연구에 참여한 정상 성인의 평균연령이 24.6세로 매우 젊은 편이고, 평균교 육년수 또한 16.1년으로 고학력에 해당하기 때문에 이중모음 단독 선택 조건의 E-Tran 보드에서 보인 0.3-0.4점 차이의 정확한 수행력 이 실제 AAC 사용자의 입장에서는 두 E-Tran 보드 유형 간의 수행 차이가 더 벌어질 수 있을 것이다. 이에 대한 보다 직접적인 근거 마 련을 위해서는 성인 AAC 사용자를 대상으로 한 추후 연구가 필요 할 것으로 보인다.

다음으로 두 조건의 E-Tran 보드 사용에 따른 반응시간을 살펴 본 결과 이중모음을 단독으로 선택할 수 있도록 제작된 E-Tran에 서 그렇지 않은 조건보다 빠르게 글자를 생성해낼 수 있는 것으로 나타났다. 두 E-Tran 조건에서의 과제수행 시 나타난 반응시간의 차이는 목표 자극어가 단모음을 포함한 것인지, 이중모음을 포함 한 것인지에 따라 서로 다른 수행을 보이는 것으로 나타났다. 이중 모음으로 구성된 1음절 비단어에 대해서는 이중모음을 단독으로 선택할 수 있는 E-Tran을 사용할 때 가장 반응시간이 짧은 것으로 나타났으며, 단모음을 복수 선택해야 하는 조건과는 약 3 초 가량 차이가 있는 것으로 나타났다.

반면 단모음이 포함된 목표 자극어를 산출할 때가 이중모음을 포 함한 목표 자극어를 산출할 때보다 두 조건의 E-Tran 모두에서 시 간이 더 단축되었으나, 단모음을 복수 선택하도록 제작된 E-Tran을 사용한다 하여 단모음으로 구성된 비단어 생성에 더 유리한 것은 아니었다. 두 E-Tran 모두 단모음 목표 자극어에 대해서는 17초대로 비슷한 소요시간을 보였다. 그러나 이중모음 단독 선택 조건의 ETran에서는 단모임을 포함한 목표 자극어를 생성할 때가 이중모음 을 포함한 목표 자극어를 생성할 때보다 평균 0.46 초 정도의 시간 단축을 보일 수 있었으나, 단모음 복수선택 조건의 E-Tran에서는 이
두 목표 자극어 유형 간의 시간 차이가 3.52 초로 극명하게 벌어졌다. 이러한 결과는 E-Tran 사용자가 다양한 모음유형을 포함한 긴 음절 의 발화 메시지를 산출할 경우 이중모음을 단독으로 선택할 수 있 는 조건과 그렇지 않은 조건 간의 소요시간이 훨씬 더 크게 나타날 수 있다는 것을 시사한다. 또한 정확도에 대한 과제수행 결과에서도 살펴보았듯이, 본 연구는 교육년수가 비교적 높은 젊은 정상 성인을 대상으로 하였기 때문에 인지적 결함과 음운지식 능력이 일부라도 손상된 장애인의 경우라면 E-Tran을 사용한 의사소통의 속도는 모 음을 어떻게 배열하고 선택할 수 있도록 하느냐에 따라 그 효과성이 크게 벌어질 것으로 보인다. 이에 대해서도 추후 임상연구를 통해 경험적 자료를 보강할 필요는 있어 보이나 본 연구에서 도출한 기초 연구 결과로도 근거 마련에 도움이 될 것으로 기대한다.

이상의 논의에서 살펴보았듯이, 이중모음을 E-Tran 보드에 그대 로 배치하여 임상과 교육 현장에서 활용할 경우, 단모음을 다중으 로 선택하여 결합해야 하는 수고로움을 경감해 주기 때문에 사용 자의 눈동자 움직임의 피로도와 인지적 부담을 감소하는 데에 긍 정적인 영향을 줄 것으로 기대된다. 특히 1 음절 이상의 다음절 단 어, 구, 문장 수준으로 메시지의 언어적 단위가 확장될수록 이중모 음을 단독으로 선택할 수 있는 E-Tran 보드의 강점은 더욱 두드러 지게 나타날 것이다. 본 연구에서는 의미단어가 아닌 비단어를 의 도적으로 사용하여 언어적 그리고 개인적 요인이 미치는 영향을 최 소화하려 하였다. 만약 의미있는 단어로 구성된 메시지를 구성하 게 된다면 다양한 의미적, 구문적, 형태론적, 화용적, 음운론적 요 인들이 함께 작용할 것이기 때문에 더 많은 인지적 부담과 언어처 리과정이 수반될 수 있다. 따라서 E-Tran 사용자들이 한국어의 발 달된 모음체계를 추가적인 인지 부담 없이 효율적으로 활용할 수 있도록 함으로써, 보다 더 빠르고 정확하게 타인과 소통하고 사회 에 참여할 수있게 될 것이다.

E-Tran 보드 사용 시 작용하는 인지능력을 이해하기 위해 비단 어 또는 의미단어 생성과제에서의 수행능력과 언어적 - 비언어적 작 업기억능력과의 연관성을 살펴볼 필요가 있으며 음절의 길이, 자소 결합의 다양성, 언어적 단위의 복잡성, 과제 유형 등에 따라 수행의 차이가 발생하는지에 대해서도 후속 연구가 이루어져야 하겠다. 마 지막으로 위에서 주지한 바와 같이 향후 연구에서는 E-Tran 보드 가 필요한 실제 의사소통장애인에게 적용하여 다양한 측정변수에 대해 다각도로 살펴보는 연구가 진행되어야 할 것으로 보인다.

\section{REFERENCES}

American Speech-Language-Hearing Association. (2004). Roles and respon- 
sibilities of speech-language pathologists with respect to augmentative and alternative communication: technical report. Available from www.asha.org/ policy.

Berninger, V. W., \& Gans, B. (1986). Language profiles in nonspeaking individuals of normal intelligence with severe cerebral palsy. Augmentative and Alternative Communication, 2(2), 45-50.

Beukelman, D. R., \& Mirenda, P. (2013). Augmentative and alternative communication: supporting children and adults with complex communication needs. Baltimore, MD: Paul H. Brookes.

Boersma, P., \& Weenink, D. (2019). Praat: doing phonetics by computer [Computer program]. Version 6.1.12, retrieved 13 October 2019 from http:// www.praat.org/

Brady, S. A., \& Shankweiler, D. (1991). Phonological processes in literacy. Hillsdale, NJ: Erlbaum

Cook, A. M., \& Hussey, S. M. (2002). Assistive technologies: principles and practice (2nd ed.). St. Louis: Mosby.

Eicher, J. H. (1973). Instruction for the ETRAN eye signaling system. Ridgefield, CT: Jack H. Eicher.

Goossens, C., \& Crain, S. (1987). Overview of non-electronic eye-gaze communication techniques. Augmentative and Alternative Communication, 3(2), 77-89.

Harris, D., \& Goren, M. (2009). The ERICA eye gaze system versus manual letter board to aid communication in ALS/MND. British Journal of Neuroscience Nursing, 5(5), 227-230.

Hart, P., Scherz, J., Apel, K., \& Hodson, B. (2007). Analysis of spelling error patterns of individuals with complex communication needs and physical impairments. Augmentative and Alternative Communication, 23(1), 16-29.

Kate, J. H., \& Hepp, B. (1989). Optical and eye-controlled communication aids. Journal of Medical Engineering \& Technology, 13(1-2), 63-67.

Kim, H., Heo, J., Kim, D., \& Kim, J. (2009). Screening Test for Aphasia and
Neurologic-Communication Disorders (STAND). Seoul: Hakjisa.

Kim, Y. T., Park, E. H., Han, S. K., \& Ku, J. A. (2016). Program of the Korean AAC Assessment (KAA) \& Intervention (KAI). Seoul: Hakjisa.

Mitsumoto, H. (2009). Amyotrophic lateral sclerosis: A guide for patients and families (3rd ed.). New York: Demos Health

Morais, J., Alegría, J., \& Content, A. (1987). The relationships between segmental analysis and alphabetic literacy: an interactive view. Cahiers de Psychologie Cognitive, 7(5), 415-438.

Park, C. (2017). Korean phonology and letters 1-focusing on pronunciation and notation. Seoul: Jisikgwa Kyoyang

Sandberg, A. D., \& Hjelmquist, E. (1996). A comparative, descriptive study of reading and writing skills among non-speaking children: a preliminary study. European Journal of Disorders of Communication, 31(3), 289-308.

Shin, J. Y. (2008). Frequency of Korean phonemes and syllables based on analysis of free speech data in adults. Korean Journal of Communication \& Disorders, 13(2), 193-215.

Shin, J. Y. (2011). The Sounds of Korean. Seoul, Korea: Knowledge and Education.

Sigafoos, J., \& Couzens, D. (1995). Teaching functional use of an eye gaze communication board to a child with multiple disabilities. British Journal of Developmental Disabilities, 41(81), 114-114.

Swift, S. M. (2012). Low-tech, eye-movement-accessible AAC and typical adults (Master's thesis). San Jose State University, California, USA.

Vanderheiden, G. C. (1980). Augmentative modes of communication for the severely speech-and motor-impaired. Clinical Orthopaedics and Related Research, 148, 70-86.

Wagner, R. K., \& Torgesen, J. K. (1987). The nature of phonological processing and its causal role in the acquisition of reading skills. Psychological Bulletin, 101(2), 192-212. 


\section{국문초록}

\section{E-Tran 보드에서의 한국어 모음 선택에 관한 연구}

\section{고정은 · 신상은}

충남대학교 대학원 언어병리학과

배경 및 목적: E-Tran 보드는 영어권 국가에서 복합적인 의사소통 대상자들을 위해 널리 사용되고 있는 비전자적 의사소통 도구이다. 특히 장애로 인해 신체 움직임이 크게 제한되어 있으나 기능적인 문해력을 갖고 있는 이들은 눈 움직임만으로 알파벳을 선택하여 메시 지를 전달할 수 있기 때문에 이러한 로우-테크 방식이 의사소통능력 증진에 큰 도움을 주고 있다. 그러나 국내에는 이에 대한 연구가 미 진한 상태이다. 한국어가 이중모음과 같은 복잡한 모음체계를 갖춘 점을 고려하여 본 연구에서는 E-Tran 보드의 모음선택 유형이 목표 자극어의 모음유형에 따라 정확도와 반응속도에 영향을 미치는지 살펴보았다. 방법: 30 명의 정상 성인(평균 연령 $=24.6$ 세, 표준편차 $=1.8$ )을 대상으로 두 개의 모음선택 조건(이중모음 단독선택 vs. 단모음 복수선택)으로 제작된 E-Tran 보드를 사용한 비단어생성과제 를 실시하였으며 정확도와 반응시간을 측정하였다. 결과: 이중모음 단독선택 조건의 E-Tran보드를 사용하였을 때 보다 정확하고 빠른 수행이 가능하였다. 특히 목표 자극어가 이중모음을 포함하고 있는 경우 단모음을 복수로 선택해야 하는 E-Tran 조건에서보다 더 나은 수행을 보였다. 논의 및 결론: 단모음과 이중모음에 대해 단독으로 선택 가능한 E-Tran 보드를 제공함으로써, 국내 AAC 사용자들이 보다 효율적인 의사소통이 가능할 것으로 보인다. 추후 연구에서는 의미단어로 구성된 다양한 언어적 단위에서도 동일한 효과가 나타 나는지를 살펴볼 필요가 있겠다.

핵심어: 보완대체의사소통, E-Tran, 모음 선택, 문해력, 성인

본 논문은 제 1 저자(고정은)의 석사학위논문의 일부를 발췌한 것임.

\section{참고문헌}

김영태, 박은혜, 한선경, 구정아(2016). 한국 보완대체의사소통 평가 및 중재 프로그램: 언어치료사 및 특수교사를 위한. 서울: 학지사. 김향희, 허지회, 김덕용, 김정완(2009). 실어증-신경언어장애 선별검사(STAND). 서울: 학지사.

박창원(2017). 한국어의 음운과 문자 1 - 발음과 표기를 중심으로. 서울: 지식과 교양.

신지영(2008). 성인 자유 발화자료 분석을 바탕으로 한 한국어의 음소 및 음절 관련 빈도. 언어청각장애연구, 13(2), 193-215.

신지영(2011). 한국어의 말소리. 서울: 지식과 교양.

\section{ORCID}

고정은(제1저자, 대학원생 https://orcid.org/0000-0002-8411-7438); 신상은(교신저자, 교수 https://orcid.org/0000-0003-0148-7829) 